\title{
'They tell me they were in fashion last year': Samuel and Elizabeth Jeake and clothing fashions in late seventeenth-century London and Rye.
}

This article examines high fashion culture in late seventeenth-century London and Rye, focusing on the ways that Rye merchant, Samuel Jeake (1652-1699), and his wife, Elizabeth (1667-1736), engaged with the London fashion market at a time when the transmission of fashion styles was still primarily by word of mouth. As we shall see, both Samuel and Elizabeth were intensely concerned to appear fashionable in provincial Rye. Correspondence between Samuel and Elizabeth and their London relatives shows how fashion information was being communicated between London and Rye and the speed with which clothing fashions changed in the capital. The discussion of Samuel and Elizabeth's engagement with fashion is framed by an analysis of contemporary satirical literature which takes the supposed obsession of the English with fashion as its theme.

KEYWORDS: Samuel Jeake, Elizabeth Jeake, Rye, Sussex, seventeenth-century clothing, seventeenth-century shopping, seventeenth-century fashion, seventeenth-century London, gender and consumption.

\section{INTRODUCTION}

In his Academy of Armory of 1688 Randle Holme described the fashions of English men:

The ancient habit used by them was a loose garment called a cloak, which they cast over their other clothes, which is breeches, doublet, hose, shoes, which are as variable in their changes as is the moon; in which respect we are termed the French men's apes, imitating them in all their fantastic devised fashions of garbs so that now the comely cloak, altogether used in the beginning of my time, is now scarce used but by old and grave persons and in place thereof come jumps, ${ }^{1}$ jackets, wide-bodied coats with sleeves, they according to the fashions being the only dress of English men so that now the saying falls true, he that will describe an English man must draw him naked with a pair of tailor's shears in one hand and a piece of cloth on his $\mathrm{arm}^{2}$

The supposed fickleness of the English in choosing their clothes was a well-worn theme. ${ }^{3}$ As early as 1542 Andrew Boorde had satirized the Englishman's obsession with fashion by depicting him naked with a pair of shears in his hand because he could not decide what to wear: 'For now I will wear this 


\section{'They tell me they were in fashion last year': Samuel and Elizabeth Jeake and clothing fashions in late seventeenth-century London and Rye.}

and now I will wear that/ Now I will wear I cannot tell what/ All new fashions be pleasant to me'. ${ }^{4}$ In 1683 the anonymous author of England's Vanity complained that 'no colour, form or fashion long contents them. One while we imitate the Spaniard, another while the French, one while the Italian, another while the Dutch. Every nation is a several pattern for us. ${ }^{5}$ Some thought this fickleness had a physiological basis: as an island race, the English were believed to be especially susceptible to the waxing and waning of the moon and the ebb and flow of the tides. ${ }^{6}$ In other words, mutability was in their blood.

\section{THE NAKED ENGLISHMAN}

So let us now meet our naked Englishman. Here is Samuel Jeake, aged 19, in his own words:

My stature was short, viz the same that was noted July 41670 [i.e. $5 \mathrm{ft} 4.6$ in.] My complexion melancholy, my face pale and lean, forehead high, eyes grey, nose large, teeth bad and distorted, number 28 [i.e. 28 teeth], hair of a sad brown and curling about this age and until after 20 had a great quantity of it but from thence it decayed and grew thin. My voice grew hoarse after I had the smallpox. My body was always lean, my hands and feet small. ${ }^{7}$

Samuel Jeake the younger was born in Rye in 1652. His mother, Frances (b.1630), died of smallpox in 1654, a week after giving birth to Jeake's sister, Frances, born alive but dead the same day. His younger brother, Thomas, born in 1653, died in 1656. Thereafter he lived alone with his father, Samuel Jeake the elder (1623-1690), a prominent Rye nonconformist, town clerk and lawyer, until 1680 when both men moved into the house of his future mother-in-law, Barbara Hartshorne (16301708) and fiancée, Elizabeth (1667-1736). ${ }^{8}$ Jeake the younger died on 22 November 1699, survived by his wife and three children, Elizabeth (b. 1694), Barbara (b. 1695) and Samuel (b. 1697). A fourth child, Francis, was born five months after his death. ${ }^{9}$ His widow Elizabeth married Rye gentleman, Joseph Tucker, in 1703 and went on to have a further two children, Philadelphia and Joseph. ${ }^{10}$

Rye, at the easternmost edge of Sussex about 75 miles from London, had been a port of national significance in the sixteenth century with a population in 1565 of about 4000 . However, in the late 


\section{'They tell me they were in fashion last year': Samuel and Elizabeth Jeake and clothing fashions in late seventeenth-century London and Rye.}

sixteenth century it entered a period of prolonged economic decline caused by the silting up of its harbour and the loss of a significant portion of its mercantile trade to London. Its population had halved by 1600 and although its economy had stabilised by the 1660s it never recovered its preeminence as a port. Modestly prosperous in the late seventeenth and early eighteenth centuries with a handful of extremely affluent merchants its status was that of a minor port and market town rather than an urban centre and it was not to experience the so-called urban renaissance identified by Peter Borsay in a number of other provincial towns during this period. ${ }^{11}$

To the extent that Jeake is known at all, it is through his astrological diary, which was edited by Michael Hunter and Annabel Gregory and published in 1988. ${ }^{12}$ Jeake records that he 'began first to set down memorandums of my life in a diary' on 18 July 1666 but the diary was in fact compiled from disparate sources (his 'memorandums') at a specific time, between 12 July and 19 November 1694. As Hunter described in the introduction, the diary is a 'conscious artefact': he clearly intended it to be read by others and, in the sense that it was written retrospectively over a relatively short period of time, it is perhaps closer to an autobiography in intent. In addition to the diary there is also an extensive collection of manuscript material associated with Jeake and his circle, including business and personal correspondence, a single business ledger and a set of Jeake's personal expenditure accounts. $^{13}$

One of Jeake's main motives in compiling the diary was to subject the events of his life to astrological analysis, which he saw as entirely compatible with a strongly providential worldview. ${ }^{14}$ The diary also details Jeake's extensive reading, his frequent illnesses and their treatment, his activities as a merchant and, to a lesser extent, aspects of his family and social life. The correspondence is predominantly about Jeake's business interests but many of the letters also contain references to current affairs, family matters and shopping requests. It is in the letters that the Jeakes' interest in fashion is primarily revealed. 


\section{'They tell me they were in fashion last year': Samuel and Elizabeth Jeake and clothing fashions in late seventeenth-century London and Rye.}

Like his father and his business partner, Thomas Miller, Jeake was a nonconformist, enduring intermittent periods of persecution in the late 1670s and 1680s which disturbed his family life and damaged his business interests. It is not clear what congregation the Rye nonconformists belonged to; most likely they were Independents although as John Spurr has shown it can be difficult to demarcate one nonconformist group from another. ${ }^{15}$ Whatever were the precise complexion of Jeake's religious beliefs they clearly did not interfere with his business interests or, indeed, with his material concerns as expressed in his diary and in his letters. Hunter notes that religion is not a particularly prominent theme in the diary which has 'an overwhelmingly worldly air'. ${ }^{16}$ Moreover, whilst providence is constantly invoked in the diary it is invariably benevolent and Jeake appears to have seen little conflict between his worldly self-interest and God's purpose for him. ${ }^{17}$

Jeake's complex business interests are explored by Hunter and revealed in his diary and correspondence; they are described only in summary here. Financed by his father, Jeake entered into trade in 1674 in partnership with his friend, the established merchant, Thomas Miller, who was eight years his senior, initially importing coarse linens from northern France. ${ }^{18}$ When French imports were banned in $1678^{19}$ Jeake had to find other commodities to trade in; in 1680 he began dealing in wool, which he bought from producers in East Sussex and Kent and exported to other English ports. He also began to lend money out at interest, either by bond or mortgage, and to negotiate bills of exchange. In the mid-1680s Jeake's trading and exchanging activities were seriously disrupted by religious persecution which obliged him to absent himself from Rye for extended periods of time. However, by 1686 he was trading again; in addition to importing linen and exporting wool, he was also dealing in hops, which he exported to London and to the West Country. The outbreak of the Nine Years War in 1689 once more disrupted Jeake's business activities and the following years saw him looking around for new investment opportunities. In 1694 he invested in new government schemes for raising war funds, buying ten tickets in the Million Adventure and becoming one of the first subscribers to the newly-established Bank of England. ${ }^{20}$ 


\section{'They tell me they were in fashion last year': Samuel and Elizabeth Jeake and clothing fashions in late seventeenth-century London and Rye.}

Whilst Jeake's business career may have been turbulent, it did bring him considerable financial rewards. What really set Jeake up as a man of substance, however, was the $£ 1000$ marriage portion he received in 1681, along with his mother-in-law's house. ${ }^{21}$ Although wealthy enough to form part of the Rye urban elite Jeake's nonconformity meant that his membership of that group was not a conventional one. Until the Toleration Act of 1689 he was denied the rights of a freeman to which his birth should have entitled him and so he could have no formal role in the town's government. But he seems to have had little interest in civic government in any case; he rarely attended the town's assembly after his election as freeman in 1690 and in 1694 he paid the corporation $£ 60$ on condition that he was excused future office-holding. ${ }^{22}$ However, both Jeake and his wife participated in conspicuous and fashionable consumption - in the clothes they wore, the exotic foods they bought and the household objects they surrounded themselves with - something which has been seen as an identifying characteristic of the urban gentry. ${ }^{23}$ They were also both highly educated. Under his father's supervision Jeake learned (amongst other subjects) Latin, Greek and Hebrew, natural philosophy, mathematics and geometry, cosmography, astronomy and astrology, poetry and history. ${ }^{24}$ Less is known about Elizabeth's education. The daughter of Rye schoolmaster Richard Hartshorne (1628-1680), she was sufficiently competent in Latin to instruct their daughter Elizabeth (Betty) during one of Jeake's prolonged absences in London. ${ }^{25}$

\section{'THE CHIEFEST EMPORIUM OR TOWN OF TRADE IN THE WORLD'26}

With a population in 1700 of about half a million, London was the largest urban centre in Europe controlling about three-quarters of English foreign trade and occupying a central position in a global trading system that extended across Europe to Asia and the Americas. It was also the largest manufacturing centre in the country, rivalling Paris and Amsterdam in the range and quality of its products. Its size and the wealth of many of its inhabitants - including the landed gentry who were spending an increasing amount of their time there - created a ready pool of consumers, encouraging innovation in product design, manufacture and sales practice. London, then, represented 'the largest 


\section{'They tell me they were in fashion last year': Samuel and Elizabeth Jeake and clothing fashions in late seventeenth-century London and Rye.}

and most concentrated market for cultural goods in the nation'. Not only did it offer the consumer unparalleled choice, its prestige meant that goods bought there had an enhanced social value. ${ }^{27}$

With such an extensive range of products on offer it is no surprise that London also had an unrivalled selection of shops. Cheapside had been the centre for luxury and fashionable goods since the fifteenth century, its eastern end dominated by textile dealers, members of the Mercers' Company which had its hall there. By the 1660 s there were silkmen on both sides of the street, as well as dealers in luxury accessories such as lace and stockings and new commodities such as coffee and tobacco. ${ }^{28}$ Immediately to the east of Cheapside on Cornhill was one of London's most elite shopping centres, the Royal (or 'Old') Exchange, which had reopened in 1671 having been partly destroyed during the Great Fire. Here small shops known as pawns sold a range of high-end goods including textiles, accessories, haberdashery, perfume and jewellery. A substantial proportion of the customers were women but men shopped there too and as Claire Walsh has shown mingling with polite society and being 'seen' were as much a draw to visitors as the luxury products on display. Rivals to the Royal Exchange were the New Exchange built in 1609 and the Exeter Exchange built in 1676 both located in the Strand of the edge of the developing West End. ${ }^{29}$

London was the undisputed fashion capital of England but, as many satirical and moralistic authors were keen to point out, its fashions were seldom home-grown. The preference of the English for the fashions of other nations has already been noted. According to the author of England's Vanity 'in wearing Dutch hats with French feathers, French doublets with collars after the custom of Spain, Turkish coats, Spanish hose, Italian cloaks and Valencian rapiers' the English man had 'likewise stolen the vices and excesses of those countries'. The taste for foreign fashion undermined the nation's moral strength by corrupting its wearers; moreover, it damaged the nation's economic strength because men and women eschewed the products of its native industries in favour of those of its European rivals. ${ }^{30}$ 


\section{'They tell me they were in fashion last year': Samuel and Elizabeth Jeake and clothing fashions in late seventeenth-century London and Rye.}

However, whilst the pan-Europeanism of contemporary fashion may have been roundly condemned, it was the nation's slavish devotion to all things French that attracted more ire. ${ }^{31}$ London's fashions were driven by France. As the anonymous author of $A$ Satire against the French noted, 'All the fantastic arts of dress we know/ Did first from France, that impure fountain, flow'. ${ }^{32}$ Those who could afford to went to Paris for their clothes but there were also French tailors in London and French shops selling exclusive millinery and haberdashery items such as fans and lace. ${ }^{33}$ Such was the nation's obsession with French fashion that French shopkeepers invented 'French' styles to satisfy their customers' insatiable demands: in his Tyrannus, or The Mode in a Discourse of Sumptuary Laws of 1661 John Evelyn claimed that he knew a French woman who had told him that 'the English did so torment her for the mode, still doubting that she brought them not over the newest edition of it, that she used monthly to devise us new fancies of her own head, which were never worn in France, to pacify her customers' ${ }^{34}$ The influence of French fashion on English clothing was reflected in the increasing use of French vocabulary, satirised in the Fop's Dictionary of 1690 which provided 'an alphabetical catalogue of the hard and foreign names and terms of the art cosmetic \&c together with their interpretations for instruction of the unlearned' ${ }^{35}$

Although London was the nation's fashion information hub, dissemination was still primarily through direct observation and by word of mouth rather than through print or other media. By the 1670 s French 'fashion' plates were circulating in London but their role in disseminating fashion information is unclear. ${ }^{36}$ There was no equivalent to France's monthly fashion periodical, the Nouveau Mercure Galant, first published in 1677 , and other types of printed material which addressed contemporary fashions were less concerned with informing its readers about what to wear as with satirising its excesses. ${ }^{37}$ It has been suggested that the pair of fashionably-dressed dolls known as 'Lord and Lady Clapham' now in the Victoria and Albert Museum, London and dating from c.1690-1700 may be early examples of the fashion dolls or 'Pandoras' that became common in the eighteenth century. ${ }^{38}$ However, even if they were, their impact would have been limited by their rarity and costliness. If you did not live in London or were unable to visit the capital regularly staying abreast of fashion 


\section{'They tell me they were in fashion last year': Samuel and Elizabeth Jeake and clothing fashions in late seventeenth-century London and Rye.}

required good London connections - friends or relatives either permanently or temporarily resident there - and a reliable London tailor. You also needed the means to purchase new items on an annual or seasonal basis.

QUARTER PAGE: FIGURE 1. Young man in fashionable winter clothes, British Museum 157.c.28. Cut out from the Nouveau Mercure Galant, October 1678, engraving and etching. (O) Trustees of the British Museum

QUARTER PAGE: FIGURE 2. Young woman in fashionable winter clothes, British Museum 157.c.28. Cut out from the Nouveau Mercure Galant, October 1678, engraving and etching. () Trustees of the British Museum

Jeake seems to have first visited London in 1667 aged 15 on what appears to have been a sightseeing trip with his father. ${ }^{39}$ The following year he spent six months in London 'for diversion' staying with his aunt and uncle in Southwark. ${ }^{40}$ Thereafter he visited London irregularly, some years not going at all, others going two or three times. His reasons for visiting London varied: in May 1672 he travelled to London to 'find a medicine for my eyes'; in May 1682 he went with his wife and mother-in-law 'for diversion'; other times he went on business. ${ }^{41}$ In October 1683 he attempted to move to London permanently to avoid prosecution for nonconformity but was unable to find any employment there and so returned to Rye the following May. ${ }^{42}$ Whilst in London he stayed with relatives, his aunt and uncle, Nathaniel and Elizabeth Bonnick, ${ }^{43}$ his cousins, apothecary John Jaye and his wife Mary and tallow chandler John Mackley and his wife Elizabeth. ${ }^{44}$ After 1690 Jeake and his wife Elizabeth usually stayed with his friend and business partner, Thomas Miller, who had moved to London in 1682 to escape religious persecution in Rye. ${ }^{45}$ During their trips to London Samuel and Elizabeth were able to make purchases for themselves, their household and their Rye friends and family. For example, in 1693 they spent a month in London, Jeake noting in his diary that 'things fitted very well for pleasure this journey, but expensive, I furnishing myself with a great deal of clothes, wherein and with other expenses laid out near $£ 40,{ }^{46}$ In addition to clothes the Jeakes bought a wide variety of 


\section{'They tell me they were in fashion last year': Samuel and Elizabeth Jeake and clothing fashions in late seventeenth-century London and Rye.}

goods in London, some utilitarian such as hair powder and wash balls, some relatively exotic such as chocolate and oranges and some highly fashionable such as the 'Japanned' furniture which Jeake bought in $1688 .{ }^{47}$ As we shall see, when Jeake was in London on his own he was able to pass on information about the latest fashions in his letters to his wife; Elizabeth did the same for her elderly mother, Barbara, teenage daughter, Betty, and Rye friends when she was in London for two months in $1701{ }^{48}$ When neither was in London they relied on their London relatives and friends to shop on their behalf and to tell them what was in fashion and what was not.

\section{'I THINK A HAT OF THE PRICE YOU WRITE OF WILL BE TOO MEAN FOR YOU’49}

Jeake provides a relatively unflattering description of his appearance aged 19: he was short, slight in body, with a pale, possibly angular face, a beaky nose and bad teeth. The man who wrote this description could hardly be accused of vanity but he does reveal a certain preoccupation with his appearance. His incipient baldness in his early twenties seems to have caused him some anxiety; a tiny scrap of paper records the astrological circumstances and consequences of a haircut in 1672 , noting that "within two or three days after the curls became more fixed, solid and perceptible than formerly but by degrees decayed'. ${ }^{50}$ The smallpox he had experienced as a child did not disfigure his face but it did damage his eyesight and as an adult he wore spectacles. ${ }^{51}$

Jeake's personal expenditure accounts which survive from January 1674 to January 1680 show that during this period his cloth, clothing accessories and footwear were mostly being bought locally and his clothes were being made up by local tailors. ${ }^{52}$ His suits were made of serge or stuff, his riding coat was made of camlet, his shirts were made of dowlas, he wore worsted stockings and cambric cravats. ${ }^{53}$ There is not enough detail in the accounts to say much about the cut or style of his clothes but they seem to have been good quality but modest, in line with contemporary male fashions (discussed in more detail below) but not especially fashionable. There is also an emphasis on practicality: in 1676 he spent 1s 10d on a pair of buskins, 3s $6 \mathrm{~d}$ on two pairs of oiled-skinned drawers and $5 \mathrm{~s} 61 / 4 \mathrm{~d}$ on a linen 'frock'. ${ }^{54}$ The countryside surrounding Rye was low-lying salt marshland 


\section{'They tell me they were in fashion last year': Samuel and Elizabeth Jeake and clothing fashions in late seventeenth-century London and Rye.}

which would have been wet and inhospitable to travellers during winter. ${ }^{55}$ Knee-length boots and waterproofed clothing would have provided Jeake with a degree of protection whether travelling on foot or on horseback. Possibly he wore his frock when shifting stock around in the warehouse. There were some signs of sartorial display, however. In 1676 he spent $£ 22 \mathrm{~s} 6 \mathrm{~d}$ on a silver-hilted sword and in 1679 whilst in London he spent $2 \mathrm{~s}$ on two pairs of silver-mounted glass buttons, 7s on a velvet cap and $8 \mathrm{~s} 2 \mathrm{~d}$ on seven yards of 'Colbertine' lace. ${ }^{56}$

By 1676 Jeake was 23 and looking for a wife which may have heightened his concern about his appearance. His first two courtships were unsuccessful but in June 1680 he resolved to seek the hand of Elizabeth Hartshorne (then aged 12 years 8 months) in marriage. This time his suit was accepted; they were betrothed the next month and married in March $1681 .{ }^{57}$ The marriage settlement, agreed prior to the betrothal, was $£ 1000$ in cash (the equivalent of about $£ 85,000$ today) together with Barbara Hartshorne’s house in Middle Street, worth (together with its contents) about $£ 200$ (approximately $£ 17,000$ today). ${ }^{58}$ Jeake marked his transition to a man of substance by ordering himself a fashionable new watch from his cousin, London watchmaker James Wightman. ${ }^{59}$ On 12 February 1681 James wrote to Jeake saying,

... [I] understand you would have a fashionable watch. That, I would advise you, is a pendulum watch as we call them which is with a spring under the balance which regulates the work so that it goes better than one with a balance only. As for the studded carcase, they are still in fashion only some alteration in the order of them. The price of such a watch will be $£ 7$ but if you fix upon such a one as Mr Smith’s it was a shilling or two under $£ 510$ s. Pray be pleased to send which you please to have and I shall take extraordinary care in making it ... ${ }^{\circ 0}$

The balance spring (or hair spring) was a spring attached to the balance wheel in mechanical timepieces to control the speed at which the wheels turned thereby controlling the rate of movement of the hands and improving the accuracy of the device. Robert Hooke claimed to have come up with the idea in 1658 and he unsuccessfully sought a patent for it in 1665. When Dutch scientist, 


\section{'They tell me they were in fashion last year': Samuel and Elizabeth Jeake and clothing fashions in late seventeenth-century London and Rye.}

Christiaan Huygens, claimed it as his own invention in 1675 Hooke protested his priority to the Royal Society and accused some of its members of leaking his designs to Huygens. The dispute between the two men became a cause célèbre in scientific circles over the next few years, ensuring that the invention - whoever's it was - was brought to watchmakers' attention. The fact that the balance spring was so successful in improving timekeeping meant that it was rapidly incorporated into watch design. The 'studded carcase' might have been made of leather, sharkskin or tortoise-shell, decorated in silver 'piqué-work' or studs. ${ }^{61}$ In the end the watch cost Jeake $£ 615 \mathrm{~s}$, which, according to Wightman, was ' $5 \mathrm{~s}$ cheaper than I have sold the worst that I have made of these sort'. ${ }^{62}$

As an enthusiastic amateur scientist Jeake was no doubt impressed with the watch's novelty and the accuracy of its timekeeping. But this was also a fashionable piece of male jewellery, intended for display. What Jeake needed now was a fashionable new suit to wear it with. This was made for him by a London tailor, with James Wightman acting as his proxy. The details of the suit are set out in a letter from Wightman to Jeake which is undated but probably written in April $1681 .{ }^{63}$

... [I] have been with my tailor about your suit but find him unwilling to make it except he have measure sent up or else one of your coats for he says it will not be well made without one of them. If you send a measure he desires that they that take it may write on it which is the breast and which is the waist ... He tells me that waistcoats are in fashion and they wear them very long ... Flowered silk is little worn but gold and silver striped is much worn ... As for the lining he says it will not be suitable to the rest if you line it with Persian taffeta but it should be a richer silk. Frost button is still in wear and gold or gold and silver upon sad-coloured cloth which is much worn as also dark greys are much in wear. The button that is in fashion is a pretty high button with ridges but they do not wear very well as I am informed but look handsome on a suit. I think a hat of the price you write of will be too mean for you; I think a beaver would do well and for $£ 3$ you may have a good one ... ${ }^{64}$

In the late seventeenth century a 'suit' of male clothes consisted of a long-line coat worn over a vest or waistcoat, and breeches - in essence, a three-piece suit although that is not how it was described by 


\section{'They tell me they were in fashion last year': Samuel and Elizabeth Jeake and clothing fashions in late seventeenth-century London and Rye.}

contemporaries. This new, English, style had first been worn by Charles II in October 1666, supposedly in an attempt to promote sartorial stability in a nation whose preference for foreign fashion was widely viewed as damaging both to trade and morality. ${ }^{65}$ To the author of England's Vanity the new style had been 'perhaps the most grave and manlike dress that ever England saw' but it 'had the unhappiness to be brought in too late, and the hard fate to be sent out again too soon ... such an influence has the French pipe to make us caper after them, in all their follies, to our own dishonour and ruin' ${ }^{66}$ Although the three-piece suit continued it did not remain unchanged; subtle changes in cut and style together with its accessories marked new trends as we can see articulated in Wightman's letter.

From 1680 the coat was cut closer to the body with a slight waist emphasis and flared skirt; pockets were placed a little higher and horizontally. Collarless waistcoats followed the line and length of the coat - as Wightman noted 'they wear them very long' ${ }^{67}$ Fabric pattern and button style could also date a suit. In Paris specialist mercers called marchands d'étoffe de soie set new trends each season for the colour and design of silk fabrics working in partnership with merchants in Lyon, the centre of France's silk-making industry ${ }^{68}$ By the 1680 s the East India Company was trying to anticipate new fashions by having samples of silk fabrics made in India and sent to London and Paris for market testing. Designs that found favour were then mass produced in India and returned to Europe for sale. ${ }^{69}$ We see these changes in fashion in the advice from Wightman's tailor that 'flowered silk is little worn but gold and silver striped is much worn' ${ }^{70}$ Which buttons were chosen for Jeake's new suit is not recorded but we do know that it was further embellished by a 'shoulder knot' - a bunch of ribbon loops or looped cord worn on the right shoulder. ${ }^{71}$

FULL PAGE: FIGURE 3. Undated letter from James Wightman to Samuel Jeake, April 1681, ESRO Frewen 5047. (O East Sussex Record Office

For a hat Wightman recommended 'beaver', which was made from felted beaver fur and sheep's wool. By the 1680s beaver skins were being imported from New France or Canada by the Hudson 


\section{'They tell me they were in fashion last year': Samuel and Elizabeth Jeake and clothing fashions in late seventeenth-century London and Rye.}

Bay Company, whose charter had first been granted in 1669. The centre of the English hatting trade was Southwark with most workshops situated in the area known as 'the Maze'. ${ }^{72}$ Wightman selected the hatband himself, advising Jeake that 'I am told a ribbon [for the hat] the same of the shoulder knot is quite out of wear and this very fashionable'. ${ }^{73}$

Jeake's new suit and hat were dispatched to him by carrier on 28 May 1681, Wightman writing, 'I hope all things will fit and please you also, I having done my best endeavour. Pray let me have a line or two that I may know whether the suit fits for I have a great desire to hear'. With the letter was enclosed a bill for $£ 217 \mathrm{~s} 8 \mathrm{~d}$ for all the items that Jeake had purchased, including his new watch and his wedding ring. ${ }^{74}$ Sadly there is no letter from Jeake confirming his receipt of the goods or commenting on his new suit but a positive reception is indicated by a subsequent letter from Wightman in which he says 'I am very glad to hear that your suit fits reasonable well'. ${ }^{75}$

The story of the suit told in Wightman's letters ends here but we can imagine the young Jeake walking through the cobbled streets of Rye wearing it with a fine linen or lace cravat at his neck, a beaver hat on his head, silk or worsted stockings on his legs, a pair of black square-toed shoes on his feet, possibly a rapier by his side and his 'pendulum watch' in his pocket. ${ }^{76}$ The one thing that is hard to imagine is Jeake's hair. As we have seen, it began to thin in his twenties. His personal expenditure accounts of 1674 to 1680 record regular payments for cutting and trimming his hair; in 1681 he was carrying combs in his pocket which we know because he recorded that they broke when he fell off his horse. ${ }^{77}$ This would suggest that he wore his own hair rather than a wig and there is no record of him purchasing or maintaining one. Whilst wigs were not worn by all men, they were highly fashionable and he may have cut a somewhat odd appearance in his new clothes without one. ${ }^{78}$ Leaving this possible anomaly aside, it is worth considering how Jeake's fashionable London suit went down in provincial Rye. With no comparable information about the clothing of his peers we can only surmise that it served a purpose in marking him out as a young man on the rise and that it was not viewed as entirely outlandish. There is little further detailed information about Jeake's clothes, the odd reference to clothing purchases in letters and a few references in his business ledger for the period 


\section{'They tell me they were in fashion last year': Samuel and Elizabeth Jeake and clothing fashions in late seventeenth-century London and Rye.}

1680-1688. We know that he continued to buy clothes in London either in person or by proxy but what those clothes looked like is unknown. ${ }^{79}$

FULL PAGE: FIGURE 4. 'Lord and Lady Clapham', a pair of fashionably-dressed dolls from the 1690s. Turned, carved, gessoed and painted wood, linen, human hair and net, 1690-1700, Victoria and Albert Museum, T.847-1974. C Victoria and Albert Museum, London

\section{'THEY BEGIN TO LEAVE OFF TRAINS FROM ALL THEIR PETTICOATS' 80}

Like her husband, Elizabeth was extremely concerned to appear fashionable. In a letter to Samuel, who was then in London, dated 26 January 1686 the eighteen-year old Elizabeth requested that he buy her a 'laced coif with a pair of ear knots if worn', adding 'the knots they are to be worn with are red, green and white'. ${ }^{81}$ These formed part of the complicated high headdresses known as 'top knots' or 'towers', much satirised in popular print, that were in fashion from the early 1680 s into the early 1700s. ${ }^{82}$ A ballad of c. 1685 observed 'some misses wear as much ribbon a top/ in this their most gaudy attire/ as if their head were a milliner's shop' and urged young women to forgo the 'a-la-mode fashions of London' ${ }^{83}$ These satires also found their way into the decorative arts: a tin-glazed painted earthenware dish from 1688 in the collection of the Fitzwilliam Museum, Cambridge is inscribed with a ballad 'The A-la-mode or the Maiden's Mode Admired and Continued by the Ape, Owl and Mistress Puss'. It features a lion, an ape and an owl wearing top knots with pinners hanging down the side of their faces. ${ }^{84}$ The owl and the ape are also wearing short capes known as night rails. The ballad's message is clear: these fashions are associated with vanity, stupidity and sexual misconduct and as such should be eschewed by respectable women. ${ }^{85}$

QUARTER PAGE: FIGURE 5. 'The A-la-mode or the Maiden's Mode Admired and Continued by the Ape, Owl and Mistress Puss'. Tin-glazed Earthenware Dish; English Delftware, 1688, Fitzwilliam Museum, Cambridge, C.1443-1928. (O) The Fitzwilliam Museum, Cambridge

However, the 'a-la-mode fashions of London' were exactly what Elizabeth wanted and if she was unable to buy them for herself on one of her trips to the capital she depended on her husband and 


\section{'They tell me they were in fashion last year': Samuel and Elizabeth Jeake and clothing fashions in late seventeenth-century London and Rye.}

London friends and family to advise her on the most up-to-date trends and make purchases for her. Letters from the late 1690s show Samuel shopping on his wife's behalf with the help and fashion advice of Elizabeth Miller, wife of his long-time friend and business partner, Thomas Miller.

Jeake frequently communicated Elizabeth Miller's fashion advice to his wife by letter and she also wrote directly to Elizabeth, although only one of her letters survives. ${ }^{86}$ Elizabeth Miller bought at least some of Elizabeth's clothing: in a letter to his wife dated 28 October 1697 Jeake told her 'I intend to send your coat and things Madam Miller has bought tomorrow per carrier', adding 'she will send you a letter to tell you your coat must be lined ...' ${ }^{87}$ Jeake had to fit in his wife's shopping requests around his business activities, something that on occasion he found onerous. 'Pray don't trouble me with any errands' he wrote to her on 14 September 1697 and on 15 April 1699 he wrote 'I have not had time yet to consider your letters about what you desire to be bought but I shall mind it next week' ${ }^{88}$

In the 1690s a fashionable woman would have been wearing a gown made up of a close-fitting bodice joined to a full pleated and trained upper petticoat or skirt, open to the front to reveal the under petticoat. Very long trains were fashionable for upper petticoats, which were often worn hitched up at the sides to create a bustle effect. Under petticoats were slightly shorter than the skirt of the gown and were trimmed with three or four tiers of horizontal lace or fringe, or with a single deep flounce at the hem. Sleeves were short, straight and ended just above the elbow, with 'ruffles' or lace or muslin frills forming cuffs. The bodice might be covered by a stomacher decorated with horizontal rows of ribbon loops and bows known as 'echelles' ${ }^{89}$ Mantuas - described by Holme as 'a kind of loose garment without and stiff bodies under them' - had been in fashion since the 1670s, initially worn over the gown like a night gown (a loose, informal gown rather than a dressing gown). ${ }^{90}$ The pale pink silk damask mantua worn by Lady Clapham, one of pair of dolls from c.1690-1700 now in the Victoria and Albert Museum, London, is T-shaped with a sack back and hangs open at the front. ${ }^{91}$ Long scarves, sometimes with the ends twisted together and pinned to one side of the bodice (known 


\section{'They tell me they were in fashion last year': Samuel and Elizabeth Jeake and clothing fashions in late seventeenth-century London and Rye.}

as 'Steenkirks') had replaced tippets as fashionable neck-wear. Top knots were worn with the front hair arranged in curls and sometimes elevated by the use of a 'palisade' or wire support. ${ }^{92}$

QUARTER PAGE: FIGURE 6. Doll's mantua, silk damask lined with taffeta, 1690-1700, Victoria and Albert Museum, T.846E-1974. C Victoria and Albert Museum, London.

In a letter to his wife dated 25 April 1699 Jeake informed her, 'Madam Miller says that trains are worn still with women's upper petticoats but not so long as formerly. As for fringe she says they wear them straight but she would not advise you to alter any for they are worn both ways'. In the same letter he wrote:

Madam Miller desires to know whether the silk you would have drawn with Indian sprigs be for a mantua or for a lining, for she says if it be for a mantua it will be so very tedious for you to work it that she would rather advise you to have it painted with lively flowers which shows exceeding well and may be done for about $15 \mathrm{~s}$ and will wear very well provided it don't come too wet, which you will have no occasion to use it in. ${ }^{93}$

Jeake received Elizabeth's reply dated 27 April (which does not survive), confirming what she wanted, and in his next letter to her of 2 May he said 'your silk is put out to paint and will be done next week and with your mantua I intend to send your best petticoat being of most value'. ${ }^{94}$ Other items that he had purchased for the Rye household including new shoes, an oven door, hair powder, six wash balls, a pair of stockings, four pillow cases, one flannel petticoat, a pair of clogs, a cut-out frock or gown for Bab (Jeake's eleven-year old niece, Barbara Hartshorne), a green girdle and 'other green ribbon' and three quarters of a yard of anterine, were put aboard a ship to be carried round the coast to Rye. ${ }^{95}$ In a post script to this letter Jeake advised: 'they begin to leave off trains from all their petticoats' ${ }^{96}$

In an undated letter to Elizabeth, probably written in April 1699, Elizabeth Miller wrote: 


\section{'They tell me they were in fashion last year': Samuel and Elizabeth Jeake and clothing fashions in late seventeenth-century London and Rye.}

... I hope your undercoat will please. It is very modish for this fashion has not been seen before this winter. It is the size they are all of; if too short the lining must eke it out at top. Those that would have them warm line them with flannel or serge, others with calico. Mr Jeake thought [you] might have something at home, old flannel or anything that will layer it out will do well; they are now of this fashion on purpose to be more without trimming. Pleat it backwards or gather it at top leaving a broad plain band on the belly ... We see a variety of undercoats since the fashion is to pin up the uppermost like a pedlar which all do that walk the streets.

She also advised Elizabeth on the latest fashions in head and neckwear, commenting:

... the pinner's headdresses remain still in the same fashion; there is discourse of dressing them high and narrow as it was formerly but I have not seen it yet. Long muslin neckcloths like to men's to tie once about women's necks with a long scarf or without is now more fashionable than sable tippets $\ldots^{97}$

In the summer of 1699 Elizabeth would have been able to receive guests and make social visits in and around Rye confidant that she was wearing the latest London fashions. Assuming she had taken Elizabeth Miller's advice, her upper petticoat would have been pinned up 'like a pedlar' to show off her fringe-trimmed under petticoat and she would have worn it without a train. Perhaps she only wore her silk mantua indoors to avoid the risk of the hand-painted 'lively' flowers being ruined by the rain. Around her neck she wore a long muslin neck-cloth, maybe a fashionable Steenkirk pinned to one side of her bodice. Her top knot may have remained relatively low, rather than 'high and narrow' since Elizabeth Miller had only been able to tell her that she had heard 'talk' of this fashion returning, rather than seeing it with her own eyes. We know that Elizabeth wore her front hair curled or 'frizzed' since she refers to it in a later letter. ${ }^{98}$ At her ears may have been a pair of diamond earrings, on her finger a diamond ring 'with the three stones and four sparks' and around her neck her pearl necklace, all items mentioned in her will of $1736 .{ }^{99}$ 


\section{'They tell me they were in fashion last year': Samuel and Elizabeth Jeake and clothing fashions in late seventeenth-century London and Rye.}

Jeake's letters to his wife together with that of Elizabeth Miller convey a sense of just how fast fashions changed in the capital. As we have already seen, new patterns in silk fabrics were introduced every year and were readily taken up by the fashion-conscious: in 1681 the governor of the East India Company, Sir Josiah Child, noted the 'general rule that in all flowered silks you change the fashion and flower every year' because English ladies would pay twice as much 'for a new thing not seen in Europe before'. ${ }^{100}$ Hairstyles and accessories also underwent seasonal changes: in May 1701 whilst in London Elizabeth wrote to her elderly mother 'tell Betty (her daughter, then aged seventeen) her hair frizzed as mine used to be is the way'. ${ }^{101}$

The seasonality of glove and fan fashions was something that Jeake found out to his cost. The ban on the import of French goods in March 1678 crippled his nascent business and left him desperately scrabbling around for new ventures. ${ }^{102}$ On 19 March 1679 he wrote to Richard Pickersgill, an English agent based in Rouen, asking him whether he was able to supply him with fans, 'jessamy' gloves and 'other things', in contravention of the ban, presumably hoping that they were sufficiently discrete in size to escape detection. ${ }^{103}$ His letter was delayed, however, and Pickersgill received it only on 1 May. The goods arrived in Rye on 13 July - 12 dozen gloves, 47 fans and 10 'papers' - and Jeake took possession of them on 19 July. ${ }^{104}$ The delay to Jeake's initial letter together with the possibly slower than anticipated arrival of the goods meant that he missed the early summer season - crucial to their successful sale. As his cousin, Anne Wightman, told him in a letter dated 10 May, '... this is the best time for the sale of them because of Whitsun tide approaching after which they will not be so valuable ...'105 Anne's interest in the goods was that she had offered to sell for them in London, having 'some friends who have occasion for some gloves and fans and other things'. ${ }^{106}$ Having missed the London season Jeake may have decided that it was best to sell them in Rye but in January 1680 he still had a significant amount of stock on his hands. ${ }^{107}$ In March 1680 he sent some of the remaining stock to Anne but by then they were a year out of date. In a letter to him dated 19 March she wrote: 


\section{'They tell me they were in fashion last year': Samuel and Elizabeth Jeake and clothing fashions in late seventeenth-century London and Rye.}

... I did send some of my acquaintances to see them as soon as they came into my hands. They would have been glad to have had them if they had been fashionable; they tell me they were in fashion last year. They send me some that were now in fashion and they differ from yours ...

Moreover, their unfashionability meant that she would be unable to sell them 'at the Change' probably the Royal Exchange close to her house in Lombard Street; instead she told Jeake that she would 'see at the street shops' [i.e. she would try to sell them at the street shops]. ${ }^{108}$ In the event and with some difficulty - Anne was able to 'put off the things' but only 'with a great deal of loss'. ${ }^{109}$ Jeake noted ruefully in his diary, 'I never sent for any more, finding this trade too full of snares and temptations to be exercised with good conscience', perhaps viewing his lack of success as a sign of God's displeasure with him in attempting to flout the trading ban. ${ }^{110}$

\section{CONCLUSION}

With the outbreak of the Nine Years War in 1689 Jeake again lost his trade with France but by then he was considerably less dependent on the French market, trading additionally in English wool and hops. War did, however, disrupt his money-lending activities; in 1694 April he recorded in his diary that he was making only five per cent on his mortgages and bonds 'upon which I could barely maintain my

family'. ${ }^{111}$ His solution was to invest in new financial products and institutions emerging in the city the Million Lottery and the Bank of England - their creation a response to the Government's need to raise revenue to fight the war. ${ }^{112}$ It was his friend, Thomas Miller, who first told him about 'the Million Adventure' whilst he was in London on other business. It was, as he noted in his diary, providential that he heard about it first-hand because he had been 'animated by the example of the Londoners'; had he heard about it by letter in Rye he may have invested nothing. ${ }^{113}$ Nevertheless, Jeake thought long and hard about the 'lawfulness' (i.e. ethics) of investing. To help him clarify his thoughts he bought and read Thomas Gataker's Of the Nature and Use of Lots but in the end he persuaded himself that since it was a 'civil lot' and 'for the necessary support of the Government at war' he could invest in it with a good conscience. ${ }^{114}$ 


\section{'They tell me they were in fashion last year': Samuel and Elizabeth Jeake and clothing fashions in late seventeenth-century London and Rye.}

Jeake's response to this new investment opportunity provides an insight into the way that he was able to reconcile wealth creation and material success with his religious and moral principles. To Jeake there was nothing wrong with making money provided it was done ethically. His financial success was a sign of God's favour, something that had been proved to him by the fact that he had survived the religious persecution of the late 1670s and 1680s. ${ }^{115}$ By extension, his material goods - whether clothing or household furnishings - were part of God's blessing. In his statement about being 'animated by the example of the Londoners' we also see the influence that the fast-moving and innovatory city had on him. Possibly he found provincial Rye rather staid; had he been successful in finding employment in London in 1683 he may never have returned.

Samuel and Elizabeth Jeake undoubtedly used their fashionable London clothing as a means of displaying their social status in Rye. But it could also be argued that - with Samuel at least - it reflected a progressive attitude to conspicuous consumption, something which has been shown to be a characteristic of the commercial and dealing trades in this period. ${ }^{116}$ As we have seen, contemporary authors typically presented the English obsession with fashion in wholly negative terms: it was imitative, morally corrupting and economically damaging. But there were a few dissenting voices who claimed that, far from being an economic drain on the nation, clothing consumption generated wealth. Not only did it encourage men to work hard so that they could afford the things they wanted but it also sustained and enhanced the various branches of the clothing industry. ${ }^{117}$ John Houghton, the author of England's Great Happiness of 1677 argued that to reject the material rewards of surplus wealth was to refuse 'to enjoy those blessings providence has heaped upon you'. ${ }^{118}$ This is a sentiment with which Jeake would have agreed.

\section{Acknowledgements}

I would like to thank Sarah Cooper and Linden Thomas for allowing me to look at the Selmes archive at the Rye Castle Museum, Christopher Whittick for his help with the Frewen archive at the East 


\section{'They tell me they were in fashion last year': Samuel and Elizabeth Jeake and clothing fashions in late seventeenth-century London and Rye.}

Sussex Record Office and for reading the article through whilst in draft, Sir George White Bt for his advice on Samuel Jeake's watch and Barbara Painter for reading the article through whilst in draft.

DANAE TANKARD combines her role as a social historian at the Weald \& Downland Open Air Museum with a part-time position as a senior lecturer in the Department of History \& Politics at the University of Chichester. This article forms part of an on-going study of seventeenth-century provincial clothing, focusing predominantly on the county of Sussex.

\footnotetext{
${ }^{1}$ Described by Holme as 'a loose coat' which 'extends to the thighs, is open or buttoned down before, or open or slit up behind half way; the sleeves reach to the wrist having the turn up sometime round, then with hound's ears and another time square'.

${ }^{2}$ Randle Holme, Academy of Armory (Chester, 1688).

${ }^{3}$ As Ruth Hentschell has observed it was 'a stock emblem for representing the absurd sartorial habits of the English'(R Hentschell, 'A Question of Nation: Foreign Clothes on the English subject' in C Richardson (ed), Clothing Culture, 1350-1650 (Aldershot: Ashgate, 2004), p. 55.)

${ }^{4}$ Andrew Boorde, Introduction to Knowledge (London, 1542).

${ }^{5}$ Anon. England's Vanity: or the Voice of God against the Monstrous Sin of Pride in Dress \& Apparel (London, 1683), p. 132.

${ }^{6}$ See S Warneke, 'A Taste for Newfangledness: The Destructive Potential of Novelty in Early Modern England', The Sixteenth Century Journal, vol. 26, No. 4 (1995), pp. 881-896.

${ }^{7}$ M Hunter \& A Gregory, An Astrological Diary of the Seventeenth Century: Samuel Jeake of Rye 1652-1699 (Oxford: Clarendon Press, 1988), pp. 117-118 (hereafter Diary). Jeake had smallpox when he was 14 (Diary, p. 89).

${ }^{8}$ Father and son moved into the house in August 1680; the marriage took place in March 1681 (Diary, pp. 153, 154).

${ }^{9}$ For a Jeake family tree see T W W Smart, 'A biographical sketch of Samuel Jeake senior of Rye', Sussex Archaeological Collections, 13 (1861), pp. 78-79. Jeake had two other children who died in infancy: Elizabeth (b. 1682; d. 1682) and Manasseh (b. 1688; d. 1690).

${ }^{10}$ The National Archives (hereafter TNA) PROB 11/662/135 (Joseph Tucker, 1733); TNA PROB 11/678/209 (Elizabeth Tucker, 1736).

${ }^{11}$ For a history of Rye in the sixteenth and seventeenth centuries see G Mayhew, Tudor Rye (Hove: Delta Press, 1987) \& S Hipkin, 'The Economy \& Social Structure of Rye, 1600-1660' (Unpublished Oxford DPhil thesis, 1985). For the built environment of Rye see D \& B Martin, J Clubb \& G Draper, Rye Rebuilt: Regeneration \& Decline within a Sussex Port Town, 1350-1660 (Burgess Hill: Domtom Publishing, 2009). P Borsay, The English Urban Renaissance: Culture \& Society in the Provincial Town, 1660-1770 (Oxford: Clarendon Press, 1989).

${ }^{12}$ The original diary is in the William Andrews Clark Memorial Library, University of California. The following section draws on the extensive introduction to the published edition which was written by Michael Hunter.

${ }^{13}$ The correspondence (FRE 4814-5358) forms part of the Frewen archive held at the East Sussex Record Office (hereafter ESRO); Jeake's business ledger covering the period 1680-1688 (RYE 145/11) is in the Rye municipal archive (also held at ESRO); Jeake's personal accounts covering the period 1674-1680 (RYEYT: N39.40) form part of the Selmes archive held at Rye Castle Museum (hereafter RYEYT).

${ }^{14}$ Hunter describes Jeake's astrology as a kind of 'secularized providentialism' (Diary, p. 19).

${ }^{15} \mathrm{~J}$ Spurr, 'From Puritanism to Dissent, 1660-1700' in C Durston \& J Eales (eds), The Culture of English

Puritanism, 1560-1700 (Basingstoke: Macmillan, 1996), pp. 234-265.

${ }^{16}$ Diary, p. 9.
} 
${ }^{17}$ Diary, pp. 10-11.

${ }^{18}$ Miller was born in 1644 (RYEYT: INV 17.71).

${ }^{19}$ In 1678 all French imports were banned in anticipation of war with France; initially intended to last three years, the ban was not repealed until 1685 .

${ }^{20}$ Diary, pp. 58-73. The Million Adventure was a project to raise $£ 1,000,000$ from subscriptions in multiples of

$£ 10$ in return for guaranteed basic annuities and the chance of winning supplementary ones (Diary, p. 70).

${ }^{21}$ Diary, p. 158.

${ }^{22}$ Diary, p. 34.

${ }^{23}$ J Stobart, 'Who were the Urban Gentry? Social Elites in an English provincial town, c.1680-1760', Continuity \& Change 26 (1) (2011), pp. 89-112.

${ }^{24}$ See Diary, p. 117 for Jeake's audit of his learning aged 19. For a discussion of Jeake's intellectual development see Diary, pp. 40-50.

${ }^{25}$ Diary, p. 37; ESRO FRE 5308.

${ }^{26}$ Edward Chamberlayne, Angliae Notitia (London, 1679), part II, p. 176.

${ }^{27}$ P Borsay, 'The London Connection: Cultural Diffusion \& the Eighteenth-Century Provincial Town', The London Journal vol. 19 (1) (1994), pp. 21-35; P Earle, The Making of the English Middle Class: Business, Society and Family Life in London 1660-1730 (London: Methuen, 1989), pp. 17-34; J Styles, 'Product Innovation in Early Modern London', Past \& Present 168 (2000), pp. 124-169. Quote from Borsay, p. 24. ${ }^{28}$ V Harding, 'Shops, Markets \& Retailers in London's Cheapside, c.1500-1700' in B Blondé, P Stabel, Jon Stobart \& Ilja Van Damme (eds), Retail Circuits \& Practices in Medieval \& Early Modern Europe (Turnhout: Brepols, 2006), pp. 155-170.

${ }^{29}$ C Walsh, 'Social Meaning \& Social Space in the Shopping Galleries of Early Modern London' in John Benson \& Laura Ugolini (eds), A Nation of Shopkeepers: Five Centuries of British Retailing (London: I B Tauris, 2003), pp. 52-79.

${ }^{30}$ Anon. England's Vanity, pp. 124-125, 130. See also 'The Fantastic Act: Or the Anatomy of England's Vanity in Wearing the Fashions of Several Nations' (British Library, Roxburghe 1. 476-477, 1633-1669) for a similar set of criticisms.

${ }^{31}$ For a discussion of 'Gallomania' in Restoration England see G Stedman, Cultural Exchange in SeventeenthCentury France \& England (Farnham: Ashgate, 2013).

32 Anon. A Satire against the French (London, 1691), p. 6.

${ }^{33}$ A Ribeiro, Fashion \& Fiction: Dress in Art \& Literature in Stuart England (New Haven \& London: Yale UP, 2005), pp. 255-258'; D De Marly, 'Fashionable Suppliers. 1660-1700: Leading Tailors and Clothing Tradesmen of the Restoration Period', The Antiquaries Journal 58 (1978), pp. 333-351.

${ }^{34}$ John Evelyn, Tyrannus, or the Mode in a Discourse of Sumptuary Laws (London, 1661).

${ }^{35}$ John \& Mary Evelyn (attributed), Mundus Muliebris; or, The Ladies' Dressing Room Unlocked ... Together with the Fop Dictionary, Compiled for the Use of the Fair Sex (London, 1690).

${ }^{36}$ There is some dispute amongst costume historians about the role of French prints in disseminating fashion information in late seventeenth-century England. Alice Dolan has argued that it is more useful to consider them 'as part of a broader attempt by France to permeate and even dominate the cultures of other European countries, rather as disseminators of specific fashion advice'. She also notes that there were 'much more effective and practical ways of disseminating information about clothing' including by the written and spoken word and through direct observation. See Alice Dolan, 'An Adorned Print: Print Culture, Female Leisure and the Dissemination of Fashion in France and England, around 1660-1779', V\&A Online Journal, Issue No. 3 (Spring 2011) http://www.vam.ac.uk/content/journals/research-journal/issue-03/an-adorned-print-print-culture,-femaleleisure-and-the-dissemination-of-fashion-in-france-and-england,-c.-1660-1779 (accessed 19 May 2015). For a recent reassessment of the role of the 'fashion' print in seventeenth-century France see E Davis, "'Habit de Qualité": Seventeenth-Century French Fashion Prints as Sources for Dress History', Dress 40 (2014), pp. $117-$ 143. See also A McShane \& C Backhouse, 'Top Knots and Lower Sorts: Print and Promiscuous Consumption in the 1690s' in M Hunter (ed), Printed Images in Early Modern Britain (Aldershot: Ashgate, 2010), pp. 337357.

37 For ballads satirising contemporary fashion see 'The Virgin's Vindication: Or the Conceited Fashionmonger' (Magdalene College, Cambridge, Pepys 5.432, 1664-1703?); 'The Young Man's Advice to Proud Ladies: Or, A Friendly Caution against their Monstrous Dress' (National Library of Scotland, Crawford 744, 1692).

${ }^{38}$ Museum numbers T.846-1974; T.847-1974. See McShane \& Backhouse, ‘Top Knots and Lower Sorts', pp. 345-346. For a discussion of fashion dolls in the eighteenth century see N McKendrick, J Brewer \& J H Plumb, The Birth of a Consumer Society: The Commercialization of Eighteenth-Century England (London: Europa, 1982), pp. 43-47.

${ }^{39}$ Diary, pp. 98-99. 
${ }^{40}$ Diary, pp. 100, 102; ESRO FRE 4816-4838.

${ }^{41}$ Diary, pp. 120, 159; ESRO FRE 5301-5315.

${ }^{42}$ Diary, pp. 164-169. His father moved to London in 1682 to escape prosecution, remaining there until 1687 (Diary, pp. 33, 161).

${ }^{43}$ Elizabeth Bonnick was Jeake the elder's sister. Nathaniel died in 1670 after which she married the Southwark glazier, Christopher Dighton (d. 1686) (Smart, 'Biographical Sketch', pp. 78-9).

${ }^{44}$ Mary Jaye was the daughter of Jeake the elder's brother-in-law, William Key, a Rye mariner who died in 1666. She married John Jaye in 1681. They lived at the Golden Lion in Fenchurch Street. Elizabeth Mackley was also the daughter of William Key. She married John Mackley in 1674. They lived in Tooley Street in Southwark (RYEYT: N39.6.1).

${ }^{45}$ Diary, pp. 33, 164. In London Miller and his wife Elizabeth lived in Dunster Court, Minster Lane, just off Fenchurch Street (ESRO FRE 5309).

${ }^{46}$ Diary, p. 222. They arrived in London on 6 June, staying with Thomas and Elizabeth Miller, returning to Rye on 6 July. There is no further information about what Jeake bought on this occasion.

${ }^{47}$ ESRO FRE 5330, 5318, 5349; Diary, pp. 193, 194. The furniture was damaged in transit, much to Jeake's fury.

${ }^{48}$ ESRO FRE 5337-5358.

${ }^{49}$ ESRO FRE 5047.

${ }^{50}$ RYEYT: N39.56.2.

${ }^{51}$ Diary, pp. 89-90. In 1676 Jeake paid 3s for a pair of 'convex' spectacles (RYEYT: N39.40).

${ }^{52}$ RYEYT: N39.40.

${ }^{53}$ Serge is a type of woollen fabric with a warp of worsted and a weft of wool, one of the so-called 'new draperies' produced in the West Country. Stuff is a coarse thickly woven cloth of wool or a wool and flax mix. Camlet is like stuff but with the wool mixed with silk, cotton, linen or Angora. Dowlas is a coarse linen cloth. Cambric is a fine, white linen cloth.

${ }^{54}$ Buskins are calf-high or knee-high leather boots. 'Drawers' or underpants were usually made of linen; Jeake may here be describing leather linings for his breeches, oiled to make them water proof. A 'frock' is a loose protective over-garment usually worn by working men.

${ }_{55}^{55}$ Mayhew, Tudor Rye, p. 14.

${ }^{56}$ The buttons are described as 'glass buttons in silver ouches'. 'Colbertine' lace is a kind of open lace with a square ground, named after Louis XIV's Minister of Finance, Jean-Baptiste Colbert.

${ }^{57}$ Diary, pp. 36-37, 149-154.

${ }^{58}$ Diary, pp. 150, 155. Money converted using The National Archives Historic Currency Converter: http://www.nationalarchives.gov.uk/currency/ (accessed 19 May 2015).

${ }^{59}$ Wightman married Jeake's cousin, Anne Keys, in 1674 (RYEYT: N39.6.1); they lived 'over against the Salutation Tavern' in Lombard Street in the parish of St Nicholas Acon (ESRO FRE 5240). He was a member of the Clockmakers' Company, gaining his freedom in 1670.

${ }^{60}$ ESRO FRE 4992.

${ }^{61}$ I would like to thank Sir George White Bt, Consultant Keeper of the Clockmakers' Museum, for his advice on Jeake's watch. For a discussion of the Hooke/Huygens controversy see L Jardine, The Curious Life of Robert Hooke: The Man who Measured London (New York: HarperCollins, 2004), pp. 197-206.

${ }^{62}$ ESRO FRE 5003.

${ }^{63}$ The date is suggested by the sequence of other letters from Wightman to Jeake between April and June 1681 (see ESRO FRE 5002, 5003, 5009, 5011, 5014, 5017).

${ }^{64}$ ESRO FRE 5047.

${ }^{65}$ For a discussion of the introduction of the three-piece suit and the ideology that surrounded it see D Kuchta, The Three-Piece Suit and Modern Masculinity: England, 1550-1850 (Berkeley \& London: University of California Press, 2002), pp. 77-90.

${ }^{66}$ Anon, England's Vanity, pp. 124-125.

${ }^{67} \mathrm{C}$ W \& P Cunnington, Handbook of English Costume in the Seventeenth-Century (London: Faber \& Faber, 1972), pp. 129-154; ERSO FRE 5047.

${ }^{68} \mathrm{C}$ H Crowston, Fabricating Women: The Seamstresses of Old Regime France (Durham \& London: Duke University Press, 2001), pp. 50, 134.

${ }^{69}$ W D Smith, Consumption and the Making of Respectability, 1600-1800 (New York \& London: Routledge, 2002), pp. 51-53.

${ }^{70}$ ESRO FRE 5047.

${ }^{71}$ ESRO FRE 5011. 
${ }^{72}$ D Corner, 'The Tyranny of Fashion: The Case of the Felt-Hatting Trade in the Late Seventeenth and Eighteenth Centuries', Textile History 22 (2) (1991), 153-178. 'The Maze' was partly destroyed by fire in June 1681 (ESRO FRE 5014).

${ }^{73}$ ESRO FRE 5011.

${ }^{74}$ ESRO FRE 5011.

${ }^{75}$ ESRO FRE 5014.

${ }^{76}$ Jeake sold a 'silver-hilted rapier' - presumably the one he bought in 1676 - in 1685 for £1 12s (ESRO RYE 145/11).

${ }^{77}$ RYEYT: N39.40; Diary, p. 156. The fall also squashed his copper tobacco box flat.

${ }^{78}$ For a discussion of wigs see S J Vincent, The Anatomy of Fashion: Dressing the Body from the Renaissance to Today (Oxford: Berg, 2009), pp. 1-11. Given Jeake's penchant for fashionable clothes it seems unlikely that his lack of a wig had anything to do with his religious convictions.

${ }^{79}$ ESRO RYE 145/11.

${ }^{80}$ ESRO FRE 5329.

${ }^{81}$ ESRO FRE 5240 (emphasis added).

${ }^{82}$ Holme, Academy.

83 'Advice to the Maidens of London to Forsake their Fantastical Top Knots' (Magdalene College, Cambridge, Pepys 4.365, 1685-1688). This and other 'top-knot' ballads are discussed by McShane \& Backhouse, 'Top Knots and Lower Sorts', pp. 337-357.

${ }^{84} \mathrm{~A}$ pinner was a long lace or linen streamer that hung down behind and to the side of the top knot.

${ }^{85}$ Object number C1443-1928. 'Cat' was slang for prostitute; owls were considered foolish; apes vain, undiscriminating and licentious (http://data.fitzmuseum.cam.ac.uk/id/object/72012, accessed 15 December 2014).

${ }^{86}$ ESRO FRE 5335.

${ }^{87}$ ESRO FRE 5317.

${ }^{88}$ ESRO FRE 5306; 5327.

${ }^{89}$ Cunnington \& Cunnington, Handbook, pp. 172-177.

${ }^{90}$ Holme, Academy. See Ribeiro, Fashion \& Fiction, pp. 246-248; Crowston, Fabricating Women, pp. 36-41.

${ }^{91}$ Museum number T.846.E-1974 (http://collections.vam.ac.uk/item/O82504/dolls-mantua-unknown, accessed 13 October 2014).

${ }^{92}$ Cunnington \& Cunnington, Handbook, pp. 177, 178, 181-185.

${ }^{93}$ ESRO FRE 5329.

${ }^{94}$ There is no record of where the silk was being painted, possibly in Spitalfields which by the 1690s was already a well-established silk-production district (see Earle, Making of the English Middle Class, pp-19-20).

${ }^{95}$ Anterine is a type of worsted with a silk warp and a wool weft.

${ }^{96}$ ESRO FRE 5330.

${ }^{97}$ ESRO FRE 5335.

${ }^{98}$ ESRO FRE 5340.

${ }^{99}$ TNA PROB 11/678/209. The ring had been her grandmother's.

${ }^{100}$ Quoted in Smith, Consumption, p. 52.

${ }^{101}$ ESRO FRE 5340.

${ }^{102}$ Diary, pp. 64-67; 137-149.

${ }^{103}$ Diary, p. 146. Jeake's letter does not survive. We know what he requested from Pickersgill's reply to him date 2 May 1679 (ESRO FRE 4943). 'Jessamy' (an archaic word for jasmine) can refer either to a light yellow colour or to a jasmine fragrance. The 'other things' were 'papers'.

${ }^{104}$ Diary, p. 147; RYEYT: N39.44.4. The goods were shipped with Rye mariner, Robert Moore (ESRO FRE 4904). The port book records that 'The Return' of Rye captained by Moore entered the port from Dieppe on 12 July but the only goods recorded were four coach horses (TNA E190/776/15).

${ }^{105}$ ESRO FRE 4892. Anne was James Wightman's wife. Whitsuntide fell between 8 to 10 June in 1679.

${ }^{106}$ ESRO FRE 4892.

${ }^{107}$ A stock account for 1679 records that he sold 6 dozen fans to Thomas Miller and 4 fans to Rye draper, Thomas Markwick (RYEYT: N39.44.4). His business ledger records that he had 6 dozen gloves and 27 fans still in stock (ESRO RYE 145/11).

${ }^{108}$ ESRO FRE 4941.

${ }^{109}$ ESRO FRE 4948. See also FRE 4945.

${ }^{110}$ Diary, 147.

${ }^{111}$ Diary, p. 233.

${ }^{112}$ For an account of Jeake's involvement with these and other schemes see Diary, pp. 69-73. 
'They tell me they were in fashion last year': Samuel and Elizabeth Jeake and clothing fashions

in late seventeenth-century London and Rye.

${ }^{113}$ Diary, p. 232.

${ }^{114}$ Diary, p. 232. T Gataker, Of the Nature and use of Lots (London, 1619).

${ }^{115}$ See Jeake's interpretation of a dream he had in 1678: 'I thought this signified the divine protection and special providence of God still preserving me out of the hands of mine enemies; \& never suffering them to ruin me' (Diary, p. 145).

${ }^{116}$ Lorna Weatherill has argued that members of the 'commercial and dealing trades' were more likely to own new types of goods in the late seventeenth and early eighteenth centuries than members of the gentry and the professions (L Weatherill, Consumer Behaviour and Material Culture in Britain 1660-1760 (London:

Routledge, 1996), pp. 166-189.

117 P Slack, 'The Politics of Consumption and England's Happiness in the Later Seventeenth Century', English Historical Review, 122, no. 497 (2007), pp. 609-631.

${ }^{118}$ John Houghton, England's Great Happiness (London, 1677), p. 18. 